\title{
The biodiversity of subaerophytic phototrophic biofilms from Maltese hypogea
}

\author{
Gabrielle Zammit ${ }^{*}$, Daniela BILli² ${ }^{2}$ Elliot ShUberT ${ }^{3}$, Jan KaštovskÝ $\dot{y}^{4} \&$ Patrizia \\ AlBerTANO ${ }^{2}$
}

${ }^{1}$ Department of Physiology \& Biochemistry, Faculty of Medicine \& Surgery, University of Malta, Msida, Malta; * corresponding author: gabrielle.zammit@gmail.com

${ }^{2}$ Department of Biology, Faculty of Science, University of Rome 'Tor Vergata', Rome, Italy

${ }^{3}$ Department of Botany, Natural History Museum, London, UK

${ }^{4}$ Department of Botany, Faculty of Science, University of South Bohemia, České Budějovice, Czech Republic

\begin{abstract}
The present study focuses on a description of the biodiversity of subaerial phototrophic biofilms occurring on archaeological surfaces in Maltese hypogean environments, namely St Paul's, St Agatha's and Abbatija tad-Dejr Catacombs, all situated in Rabat and the ancient Hal Saflieni Hypogeum at Paola, Malta. Direct observation of the biofilms, carried out using light (LM), epifluorescent and confocal laser scanning microscopy (CLSM), allowed the description of the major cyanobacterial and microalgal taxa, and also the associated heterotrophic microorganisms, mainly actinobacteria. Some biofilm microorganisms were able to grow in culture and this allowed the isolation of cyanobacterial, microalgal and chemoorganotrophic bacterial strains. Thylakoid arrangement and cell division were examined using transmission electron microscopy (TEM). The cytomorphology of isolated microorganisms was described. The undisputed phototrophic protagonists in these subaerial biofilms of Maltese hypogean environments were the non-heterocytous (Oscillatorialean) cyanobacteria. In order to increase the limited data available for Leptolyngbya spp. from aerophytic epilithic biofilms in catacombs, the 16S rRNA genes of isolated Leptolyngbya strains were sequenced and compared with those obtained for related strains. Phylogenetic trees of cyanobacterial 16S rRNA sequences were constructed using parsimony and Bayesian analyses. Microorganisms forming biofilms in Maltese hypogea were found to be similar, both cytomorphologically and genetically, to those colonising lithic surfaces of caves and catacombs in other Mediterranean countries.
\end{abstract}

Key words; catacombs, cyanobacteria, cyanoprokaryotes, hypogea, Leptolyngbya, microalgae, Oscillatoriales, phototrophic biofilms, Stigonematales, subaerophytic

\section{Introduction}

The phototrophic microbial biofilms occurring in Maltese hypogea are multi-layered structures composed of physiologically different groups of microorganisms. The most important primary producers in this ecosystem are the filamentous cyanobacteria and Chlorococcal microalgae. These are accompanied by Chroococcalean cyanobacteria, filamentous microalgae, diatoms, moss protonema, actinobacteria, and grampositive bacilli (ZAMMIT et al. 2009). The microorganisms are normally surrounded by thick extracellular polymeric substances (EPS), which glue the biofilm to the substratum.

The most comprehensive studies of subaerial biofilms from catacombs have been carried out on the three catacomb sites dedicated to St. Domitilla, St. Callistus and Priscilla in Rome, Italy. Different species of terrestrial epilithic cyanobacteria belonging to the genera Eucapsis Clements et Shantz 1909, Leptolyngbya AnAGNOstidis et KomÁreK 1988, Scytonema AgARdH ex Bornet et Flahault 1887, and Fischerella (BoRnet et Flahault) Gomont 1895, were found to occur as dominant organisms in these phototrophic microbial communities. A few species of green algae and the diatom Diadesmis gallica W. SмIтн 1857 occurred in minor amounts (ALBERTANO et al. 1989; AlBertano et al. 1995). The most frequently occurring actinobacteria were the streptomycetes; Streptomyces WaKsman et HenRICI 1943, Nocardia TrevisAn 1889 and Micrococcus COHN 1872. 
Analysis of partial 16S rRNA sequences revealed that many isolates were of novel species. Other bacteria detected in the air samples were mostly Gram-positive chemoorganotrophs belonging to the genera Staphylococcus Rosenbach 1884, Microbacterium OrLa-Jensen 1919 and Bacillus CoHN 1872. Gram-negative bacteria were a minority among the isolated bacteria, and were species belonging to Pseudomonas Migula 1894, Stenotrophomonas Palleroni et BRAdBuRY 1993, Pectobacterium WaldeE 1945 and Acinetobacter BRISOU et PRÉvot 1954. Most of the anaerobically growing bacteria were Gram-positive cocci, mainly facultative anaerobic species of Staphylococcus Rosenbach 1884. Fungi, mainly white Lecanicillium psalliotae (TRESCHEW) ZARE et W. Gams 2001, L. Aranearum (Ретсн) Zare et W. Gams 2001, species of Torrubiella BoudiER 1885 and Beauveria alba (LimBer) SACCAS 1948 were isolated to a lesser extent than bacteria from both air and biofilm samples (SAARELA et al. 2004).

The structural relationships among phototrophic and chemoorganotrophic microorganisms forming subaerophytic biofilms inside catacombs environments in Rome have also been studied (Albertano \& Urzi 1999). There is often an intimate association between actinobacteria, mainly Streptomyces spp., and filamentous cyanobacteria. It is however difficult to observe direct contact, and indeed direct cell wall association has only been reported between Leptolyngbya sp. and a filamentous bacterium, identified possibly as Streptomyces sp. (AlBertano et al. 1989). The EPS produced by cyanobacteria are able to mediate metabolite exchange and serve as an excellent growth substratum for a variety of heterotrophic bacteria (PAERL 1992).

Cyanobacterial diversity in nature (GARCIA-PICHEL et al. 1998; TAтоN et al. 2002) is substantially wider than is recognisable phenotypically, and for instance, only $5-10 \%$ of the real diversity particularly in tropical and extreme biotopes has been acknowledged (WATANABE 1999).

At present, both the cyanobacterial (KoMÁReK 2003) and microalgal (LOPEZ-BAUTISTA et al. 2007) taxonomic systems are in dire need of revision. Only a number of well-characterised and clearly distinct genera are easily defined (KомÁREK et al. 2003; LopeZ-BAutisTA et al. 2007). Infra-generic criteria are still not clear (КомÁReK 2002) and the species concept, especially in cyanobacteria, is still being defined according to molecular criteria (KoMÁreK 2003).

In the present study, a polyphasic approach was applied (ANAGNOSTIDIS \& KomÁReK 1985a; Wilmotte \& Golubić 1991) that combined morphological, ultrastructural as well as ecological and molecular criteria. In particular, the $16 \mathrm{~S}$ rRNA gene was used to identify bacterial genera and 18S rRNA gene for eukaryotic groups. Apart from a general study of the biofilm diversity, this research was also concerned with the description of members of the genus Leptolyngbya in Maltese hypogean environments.

\section{Materials and Methods}

Sampling. Subaerial phototrophic biofilms occurring as pigmented alterations on the archaeological surface of the Maltese palaeo-Christian catacombs dedicated to St Paul, St Agatha and Abbatija tad-Dejr, situated in Rabat and the ancient Hal Saflieni Hypogeum at Paola were sampled during the period between May 2005 and November 2007. Sampling was conducted using non-invasive sampling methods by which only the biofilm was sampled and not the underlying substratum. Samples were removed using adhesive tape strips (Urzi \& De Leo 2001) and damp sterile filter paper. Environmental variables such as the light intensity and photoperiod, relative humidity, substrate preference and the visible presence of water were recorded for each sample (ZАмmiт et al. 2008a, 2008b, 2009). Samples were stored at $4{ }^{\circ} \mathrm{C}$ and subsequently investigated as described below.

Cultures. For the isolation of microorganisms, strips (2 $\times 2 \mathrm{~cm}$ ) of adhesive tape and filter paper were streaked directly onto Petri dishes containing agarised culture media under sterile conditions. The nutrient media used were specific for the isolation of: heterotrophic bacteria (GYM after LERCH \& ETTLINGER 1972, without $\mathrm{CaCO}_{3}$ ); cyanobacteria (BG11, both enriched with nitrates and without, after Allen 1968); eukaryotic microalgae (BBM enriched with vitamins after Bischoff \& Bold 1963); and fungi (DRBC after KING et al. 1979). During the preparation of all liquid and agarised media, the $\mathrm{pH}$ was adjusted to 7. Incubation for chemoorganotrophic organisms was carried out at $28^{\circ} \mathrm{C}$ for one month and investigations ensued as described in ZамmIT et al. (2008a). Phototrophs were cultured at $18^{\circ} \mathrm{C}$ and a light intensity of $8 \mu \mathrm{mol} \cdot \mathrm{m}^{-2} \cdot \mathrm{s}^{-1}$.

The growth of phototrophic microorganisms in culture was initially very slow. Various approaches were followed in order to produce unicyanobacterial 
or unialgal cultures. Continuous sub-culturing was carried out in the same medium which helped to obtain effective results. The mechanical separation by micromanipulation and repeated transfer of cells allowed successful isolation. The purity of the cultures was checked regularly under the light microscope. After one year of growth on agarised media, isolates were also transferred to liquid media, where better growth was obtained.

Microscopy. Direct observation of biofilms was carried out using light and fluorescence microscopy. Sections approximately $1 \times 1 \mathrm{~cm}$ were cut from adhesive tape samples (Urzi \& De Leo 2001). These were labelled with the following fluorochromes; 3 $\mu \mathrm{g} . \mathrm{ml}^{-1}$ Acridine Orange (AO) for nucleic acids and polysaccharides, $50 \mu \mathrm{g} \cdot \mathrm{ml}^{-1}$ fluorescein isothiocyanate conjugated to Concanavalin A (FITC-conA) for $\alpha-D$ mannopyranosyl and $\alpha-\mathrm{D}-$ glucopyranosyl residues and $15 \mu \mathrm{g} \cdot \mathrm{ml}^{-1}$ 4,6-diamidino-2-phenylindole (DAPI) for DNA localisation. Observations were carried out using an Olympus 1X70 Delta Vision System (Applied Precision) equipped with a mercury lamp (103W/2 OSRAM 1XHBO) and 360-440 nm, 490-520 nm and 555-628 nm excitation filters and $457-470 \mathrm{~nm}, 528$ $538 \mathrm{~nm}$ and $617-673 \mathrm{~nm}$ emission filters.

Undamaged and intact biofilm fragments were transferred to cavity microscope slides. They were incubated in FITC-conA for $40 \mathrm{~min}$ in the dark. An Olympus Ix81 CLSM was used. Wavelengths of the excitation lasers were in the blue $(488 \mathrm{~nm}$; Ar) green (543 nm; Ar/HeNe) and red (635nm; Ar/ $\mathrm{HeNe}$ ) regions. Images were acquired in the three channels simultaneously; red channel for pigment autofluorescence, green channel for labelled EPS and blue channel for calcite autofluorescence.

For TEM, micro-samples were fixed in $2.5 \%$ glutaraldehyde and post-fixed in a $1 \%$ osmium tetroxide solution, dehydrated in a graded ethanol series, and embedded in an epoxy 812 Resin Kit (Multilab Supplies, England). Thin sections were collected on copper grids for contrast staining with salts of uranium (uranyl acetate) and lead (lead citrate) (REYNOLDS et al. 1963) to reveal cell ultrastructure. Thin sections were also collected on gold grids for cytochemical staining with periodic acid for the detection of polysaccharides with unsubstituted vicinal $\mathrm{OHs}$ such as glycogen (THIERY 1967), and with phosphotungstic acid (PTA) in $\mathrm{HCl}$ for positively charged glycoproteins (RoLAND et al. 1972). Thin sections were observed using a HITACHI $\mathrm{H}-7100$ operating at $100 \mathrm{kV}$.

The cyanobacterial and microalgal isolates grown in culture were studied by means of LM and TEM. Identification was based on taxonomic monographs and reference books for terrestrial algae and cyanobacteria
(Printz 1939, 1964; Migula 1907; Geitler 1932; Prescott et al. 1972; Ettl 1978, 1983; KomÁreK \& Fott 1983; Krammer \& Lange-Bertalot 1986, 1988, 1991a, b; EtTl \& GÄrtner 1988, 1995; KomÁrek \& AnAgnostidis 1998, 2005; Rindi et al. 2005; JOHN et al. 2002; WeHr \& SHEATH 2003).

Molecular analyses. DNA was extracted from biofilms and isolates using the UltraClean Soil DNA Isolation Kit (Mo Bio Laboratories) according to the manufacturer's protocol.

The 16S rRNA gene was amplified using the cyanobacterial specific primers 2 (5'-GGG GGA TTT TCC GCAATG GG-3') and 3 (5'-CGC TCT ACCAAC TGA GCT A-3') after BOYER and co-authors (2001). PCRs were carried out in $25 \mu \mathrm{l}$ aliquots containing approximately $100 \mathrm{ng}$ DNA, a deoxynucleoside triphosphate mixture $(0.2 \mathrm{mM}$ each), buffer $(1 / 2$ volume of the supplied $2 \times$ buffer) supplemented to give a final concentration of $2.5 \mathrm{mM} \mathrm{MgCl}_{2}, 1.25 \mathrm{U}$ of Taq polymerase (all components supplied by Top-Bio, Czech Rep.), and 0.5 pmol of each primer. The profile used was $1 \min 30 \mathrm{~s}$ at $95^{\circ} \mathrm{C}, 40$ cycles at $95^{\circ} \mathrm{C}$ for $1 \mathrm{~min}, 52^{\circ} \mathrm{C}$ for $1 \mathrm{~min}, 72^{\circ} \mathrm{C}$ for $2 \mathrm{~min}$, and a final elongation step of $7 \mathrm{~min}$ at $72^{\circ} \mathrm{C}$. Amplifications were run in a Biometra T3000 Thermocycler or TC-XP Bioerg cycler.

The 18S rRNA genes were amplified using the primer pairs P73 (5'-AAT CAG TTA TAG TTT ATT TGR TGG TAC C-3') and P47 (5'-TCT CAG GCT CCC TCT CCG GA-3') (BERARD et al. 2005) and EukA (5'-AAC CTG GTT GAT CCT GCC AGT- 3') and EukB (5'- TGA TCC TTC TGC AGG TTC ACC TAC-3') (DiEz et al. 2001). PCRs were carried out in $25 \mu \mathrm{l}$ aliquots containing approximately $100 \mathrm{ng}$ DNA, a deoxynucleoside triphosphate mixture $(0.2$ $\mathrm{mM}$ each), buffer (1/10 volume of the supplied $10 \mathrm{x}$ buffer) supplemented to give a final concentration of $3 \mathrm{mM} \mathrm{MgCl}_{2}, 1 \mathrm{U}$ of Taq polymerase (Promega), and $0.5 \mathrm{pmol}$ of each primer. Amplifications were run in a GeneAmp PCR system 2700 (Applied Biosystem) as follows. For the primer pair P73-P47, the profile used was; 1 cycle of $1 \mathrm{~min}$ at $94{ }^{\circ} \mathrm{C} ; 37$ cycles of $1 \mathrm{~min}$ at $92{ }^{\circ} \mathrm{C}, 50 \mathrm{~s}$ at $57{ }^{\circ} \mathrm{C}$ and $50 \mathrm{~s}$ at $72{ }^{\circ} \mathrm{C}$ and a final elongation step of $10 \mathrm{~min}$ at $72{ }^{\circ} \mathrm{C}$. For the primer pair EukA-EukB, the profile used was; 1 cycle of 2 min at $95^{\circ} \mathrm{C} ; 35$ cycles of $15 \mathrm{~s}$ at $92{ }^{\circ} \mathrm{C}, 50 \mathrm{~s}$ at $50{ }^{\circ} \mathrm{C}$, and 2 min at $72{ }^{\circ} \mathrm{C}$; and a final elongation step of $10 \mathrm{~min}$ at $72{ }^{\circ} \mathrm{C}$.

PCR products were checked on $1.4 \%$ (w/v) agarose gel. Successful amplifications were purified using JetQuick PCR Purification Kit (Genomed) and cloned into pGEM-T Easy Vector System (Promega) according to the supplier's manual and using competent Escherichia coli DH5 alpha cells. Competent cells were transformed 
by heat shock, and aliquots of white colonies were transferred to $20 \mu \mathrm{l}$ of sterile water, heated for $5 \mathrm{~min}$ at $94^{\circ} \mathrm{C}$ and then $0.4 \mu \mathrm{l}$ were used as template in 10 $\mu \mathrm{l}$ of PCR total volume. The PCR setup and cycling conditions were the same as for initial amplification.

After cloning, one strand of the 16S rRNA genes obtained from biofilms was sequenced by a commercial company (BMR genomics, Padova, Italy). The partial $16 \mathrm{~S}$ and $18 \mathrm{~S}$ gene sequences were compared with sequences available in the GenBank nucleotide database using the BLAST algorithm (Altschul et al. 1990) in order to obtain an overview of the biodiversity in each biofilm.

The cloned 16S rRNA genes obtained from isolates were sequenced using BigDye Terminator v3.1 Cycle Sequencing Kit (Applied Biosystems) on ABI 3730x1 DNAAnalyser (Applied Biosystems) in the Laboratory of Genomics at the Biology Centre ASCR and Faculty of Science, University of South Bohemia, České Budějovice. The amplification primers were used as the sequencing primers.

Nucleotide sequences of 16S rRNA genes, obtained from cyanobacterial isolates in this study and related sequences retrieved from GenBank, were aligned using CLUSTALX algorithm implemented in Bioedit 7.0.9.0 (HALl 1999), refined and used to generate a phylogenetic tree. Similar reliable sequences were selected from GenBank based on their length, in order to obtain a representative sample of the taxonomic variation. Gloeobacter violaceus PCC7421 was used as the outgroup. Phylogenetic trees were inferred by neighbor-joining (NJ) and maximum-parsimony (MP) methods in PAUP v. $4.0 \mathrm{~b} 10$ (SWOFFORD 2002) and Bayesian inference (MB) in MrBayes 3.1.1 (RoNQuIST \& HuelsenBeCK 2003). MP analysis was carried out using the heuristic search with tree-bissectionreconnection algorithm (TBR) of ten replicates with random stepwise addition and the MulTrees option. For neighbour-joining, corrected distance were calculated with the HKY85 model (Hasegawa et al. 1985). The robustness of branches was tested by bootstrap analysis on 1000 replicates.

For Bayesian analysis, two runs with four chains each were run simultaneously for 1,000,000 Markov Chain Monte Carlo (MCMC) generations starting with a random tree. The likelihood model was set to a general time reversible model (RoDRíGUEZ et al. 1990) including estimation of invariant sites and assuming a discrete gamma distribution with six rate categories $(\mathrm{GTR}+\mathrm{I}+\mathrm{G})$. No molecular clock was assumed. The temperature of a hot chain was set empirically to 0.1 and trees were sampled every 100 generations. The standard deviation between the two MCMC runs was below 0.01, indicating convergence. The first 2500 trees were discarded as the burn-in phase and a $50 \%$ majority rule consensus tree was calculated including posterior probabilities.

\section{Results and Discussion}

\section{The biofilms}

The microbial consortium growing on archaeological surfaces formed thick, complex, multistratified biofilms in close proximity to the entrances, and thinner, more compact biofilms further inside the hypogea. The number of taxa within a particular subaerial biofilm was highly dependent on the micro-environmental parameters; more specifically the biodiversity increased with an increase in light intensity/ photoperiod (which never exceeded $10 \mu$ mol.photons. $\mathrm{m}^{-2} \cdot \mathrm{s}^{-1}$ ) and the degree of wetness of the surface. Environmental parameters were seasonally stable; the relative humidity always exceeded $90 \%$, while the temperature ranged between 18 and $20{ }^{\circ} \mathrm{C}$. The subaerophytic biofilms grew preferentially on calcite and gypsum substrata; the type of growth and biofilm morphology was dictated by the microenvironment (surface roughness, light availability and degree of wetness). The limited amount of photosynthetically active radiation provided an effective selection pressure and proved to be the principal determinant factor as to which taxa prevailed on the archaeological surface and as to whether a biofilm tended towards autotrophy (cyanobacteria and microalgae) or heterotrophy (bacteria).

The undisputed phototrophic protagonists in the subaerial biofilms of Maltese hypogean environments were filamentous cyanobacteria; both non-heterocytous (Oscillatorialean) (Fig. 1) and heterocytous (Stigonematalean, Nostocalean). These dominated at Saint Agatha's and Saint Paul's Catacombs. Associated with the cyanobacteria were microalgae; the prevailing types are Chlorococcalean (Chlorellalean) at $\mathrm{St}$ Paul's catacombs and the Hal Saflieni Hypogeum, and filamentous (Trentepohlialean) at Abbatija tad-Dejr. Chroococcalean cyanobacteria and chemoorganotrophic bacteria were also present.

Micro-environmental parameters determined which microorganisms prevailed in a specific hypogeum. Chlorococcalean microalgae dominated at the Hal Saflieni Hypogeum where 

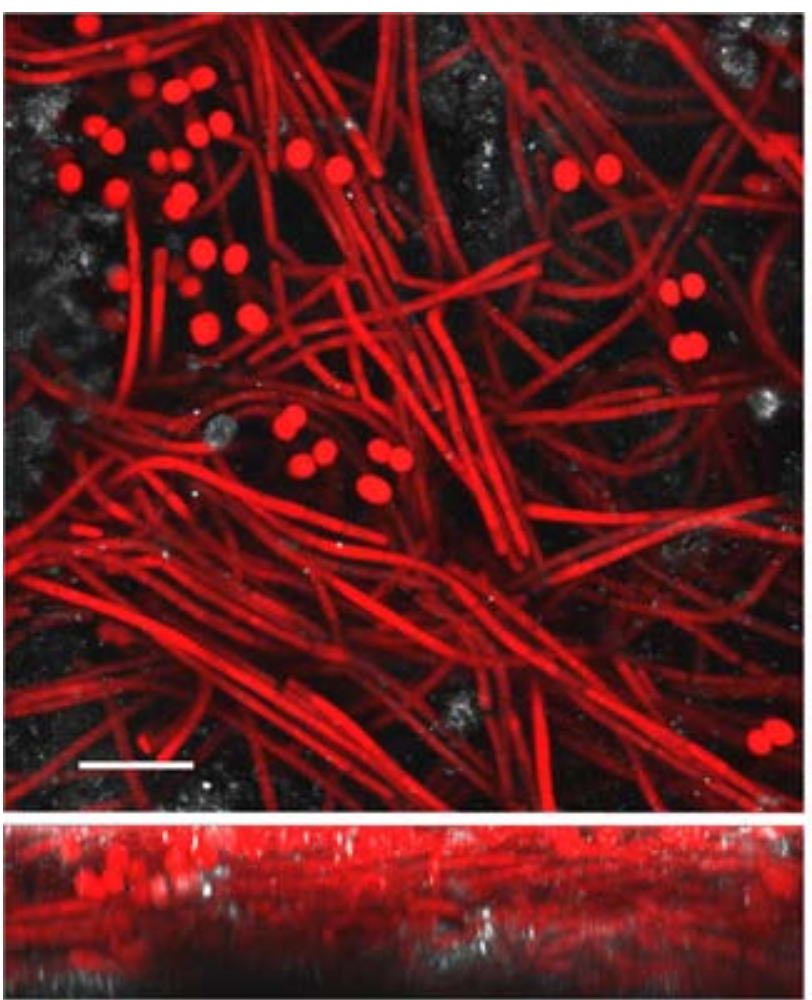

the internal environment has been under strict climatic control for the past twenty years. They were also abundant at Saint Paul's Catacombs, where they formed bright green biofilms over ochre inscriptions that were recently covered by a layer of plexiglass with an underlying light source. Filamentous microalgae prevailed at the Abbatija tad-Dejr Catacombs where the incidence of natural light was the highest.

A morphological and ultrastructural description of microorganisms belonging to the most common taxa present in these subaerophytic biofilms is given below. Table 1 lists the most common taxa forming the biofilms growing at the different hypogea. The cytomorphological and molecular characterisation of the filamentous cyanobacterial strains isolated from the same biofilms is discussed at the end.

\section{Biofilm organisms}

\section{Cyanobacteria}

Undoubtedly the most common filamentous cyanobacterial morphotype identified growing in biofilms from all four hypogean sites under study belonged to the genus Leptolyngbya (Oscillatoriaceae, Oscillatoriales) (Fig. 1). Leptolyngbya spp. from Maltese hypogea were

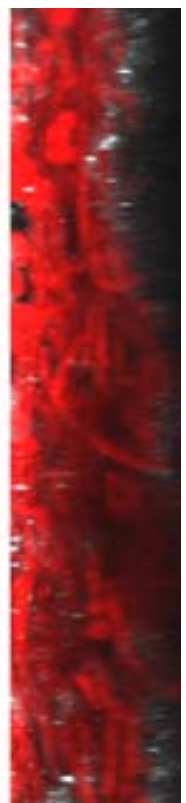

Fig. 1. 3-dimensional confocal laser scanning microscopy reconstruction of biofilm SA 38, composed predominantly of filaments of Leptolyngbya sp. together with coccal cyanobacteria. Red autofluorescence is of cyanobacterial phycobiliproteins, while the autofluorescence of calcite is white. Scale bar $15 \mu \mathrm{m}$.

characterised by thin uniseriate trichomes $(<4 \mu \mathrm{m})$ surrounded by very thin, transparent, sometimes invisible, sheaths and a parietal arrangement of thylakoids. A number of strains were isolated in culture (results below) and their life cycle and cytomorphology are presently being examined in more detail. Members of this cosmopolitan form-genus Leptolyngbya are widely distributed in numerous ecosystems and have also been isolated from the catacombs of Rome (BRUno et al. 2006, 2009) and from cryptogamic crusts in desert soils across the western United States (Evans \& Johansen 1999). The heterogeneity of Leptolyngbya has long been recognised (AlberTano \& KovÁČIK 1994) and its separation into different genera is expected according to molecular as well as ultrastructural and ecophysiological criteria (KOMÁREK 2007).

Filamentous cyanobacteria belonging to the genus Pseudanabaena LAUTERBORN 1915 were observed growing in the algal biofilm AD03 (Fig. 2b). These Pseudanabaena spp. (Pseudanabaenaceae, Oscillatoriales) were non-heterocytous cyanobacteria characterised by simple trichomes less than $4 \mu \mathrm{m}$ wide. The cells were longer than wide, they possessed parietal thylakoids and the cross walls were conspicuously constricted.

A number of filamentous heterocytous cyanobacterial species of Nostoc VAUCHER ex Bornet et Flahault 1888 (Nostocaceae, Nostocales) were observed growing in biofilms at St Agatha's Catacombs and Abbatija tadDejr. Nostoc spp. formed microscopic green colonies on the surface of calcareous substrates. Phenotypically, the filaments were made of chains of vegetative cells, nitrogen-fixing heterocytes and spore-like akinetes. Nostoc is common in both terrestrial and aquatic habitats (DoDDs et 
al. 1995). The life style is photoautotrophic, diazotrophic and also facultatively heterotrophic, such as in N. punctiforme (Meers et al. 2001). The ability of Nostoc spp. to fix atmospheric $\mathrm{N}_{2}$ and to produce a glycan EPS (HeLm et al. 2000) provided a considerable advantage for Nostoc spp. to grow on the hypogean surfaces being considered in this study.

As regards the branching heterocytous filamentous types, these morphotypes were easily observed in biofilms from the catacomb sites dedicated to St Agatha's and St Paul's. Filaments with the true V- type branching indicative of Loriella BoRzì 1892 and the false branching of Scytonema were observed occasionally. However, strains belonging to these genera were not isolated in culture, and it is common, especially for the dichotomously branching taxa, to be rare in cultures and in phylogenetic analyses (GUGGER \& HofFmann 2004). On the other hand, strains of the Fischerella morphotype, with true T-type branches, were frequently observed to form biofilms colonising the archaeological surface in these two catacombs and were successfully isolated in culture. Cyanobacteria belonging to Fischerella spp. and Scytonema spp. have also been observed to form biofilms in the catacombs of Priscilla and San Callistus in Rome (Albertano \& BelLezZA 2001) and members of Loriella sp. in Spanish caves (HERNÁNDEZ- MARINÉ et al. 1999).

The coccal (Chroococcales) types observed directly in the biofilms by LM and CLSM include Chroococcidiopsis spp. GEITLER 1932 growing in two biofilms: SA21 and SA27, at St Agatha's and three biofilms: SP01, SP02 and SP07, at St Paul's Catacombs. 16S rRNA sequences of uncultured Chroococcidiopsis sp. clones were obtained from biofilm SA27. Chroococcidiopsis cells observed growing in the biofilm produced abundant EPS, which may play a central role in desiccation
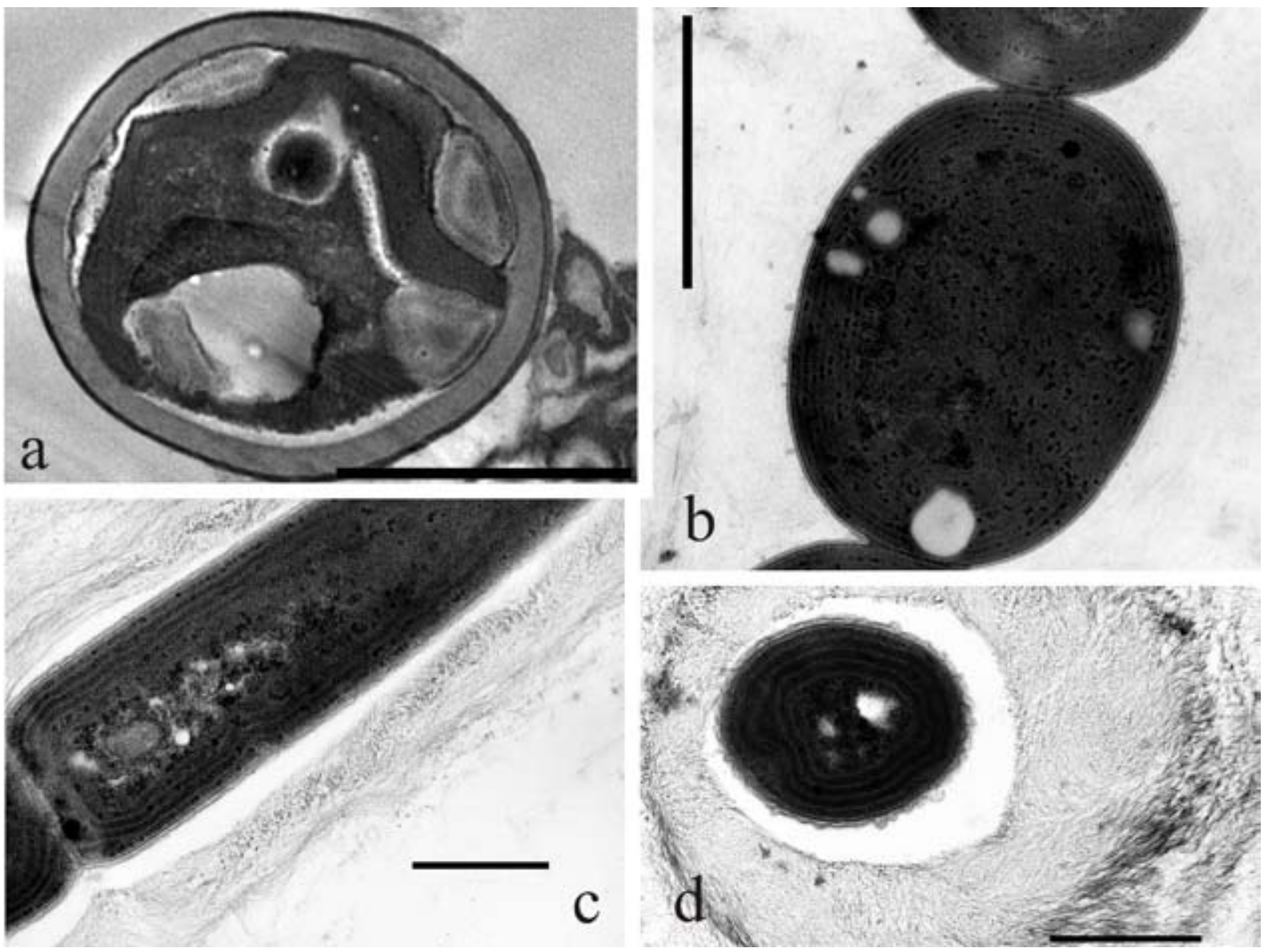

Fig. 2. TEM micrographs: (a) a microalgal cell from biofilm HYP714 with a thick sheath and a cup-shaped chloroplast; (b) Pseudanabaena cells with concentric arrangement of thylakoids; (c-d) Leptolyngbya sp. strain SP301 showing (c) parietal thylakoids and (d) a thick multilayered mucilaginous sheath made of distinct layers of fibrils. Scale bar $2 \mathrm{~mm}(\mathrm{a}, \mathrm{b}), 1 \mu \mathrm{m}(\mathrm{c}$, d). 

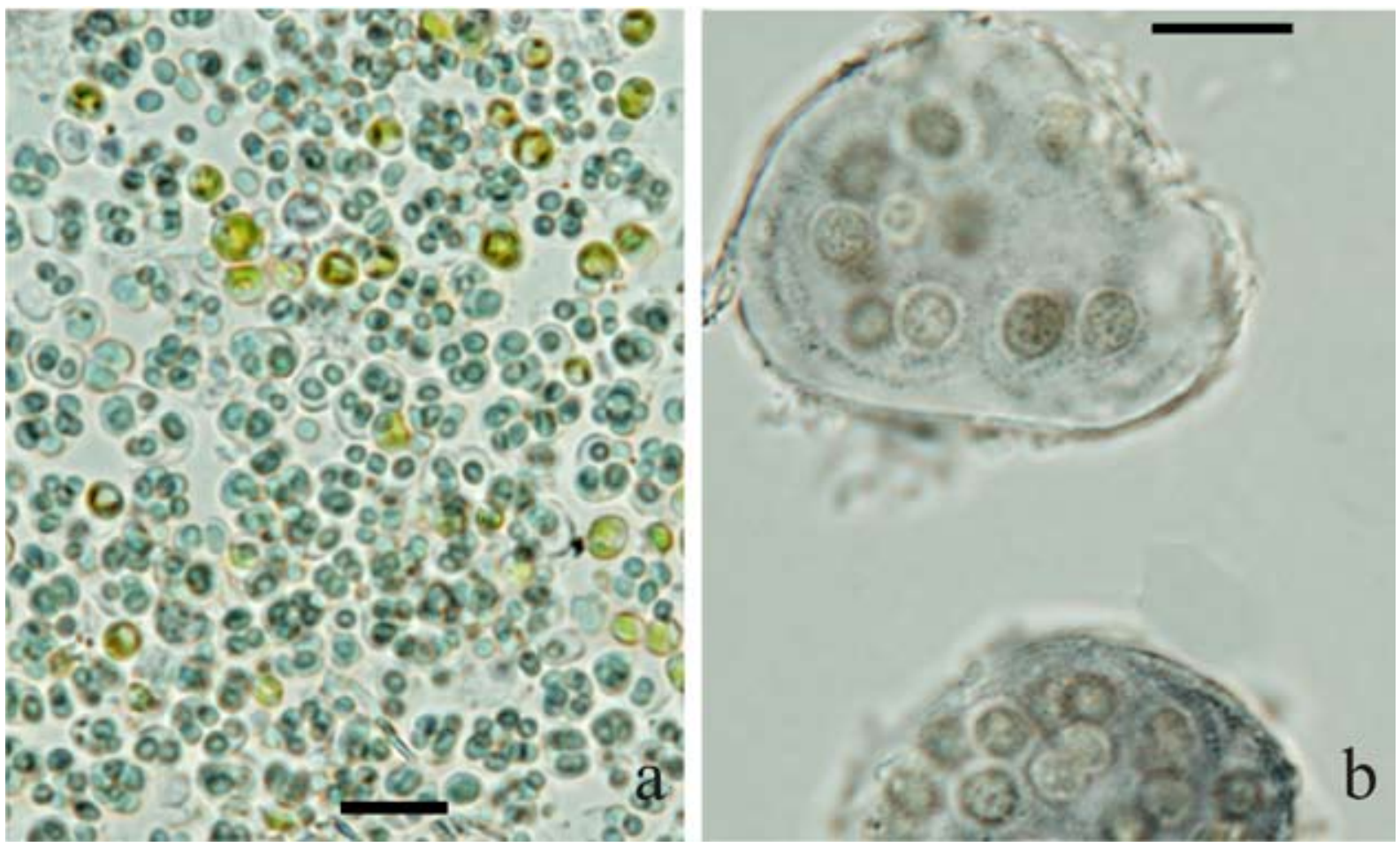

Fig. 3. Chroococcalean cyanobacterial morphotypes: (a) Gleocapsa cf. aeruginosa and coccal green algae growing in culture from biofilm HYP708, and (b) Asterocapsa cf. divina from biofilm SA36 growing in culture Scale bar $10 \mu \mathrm{m}$.
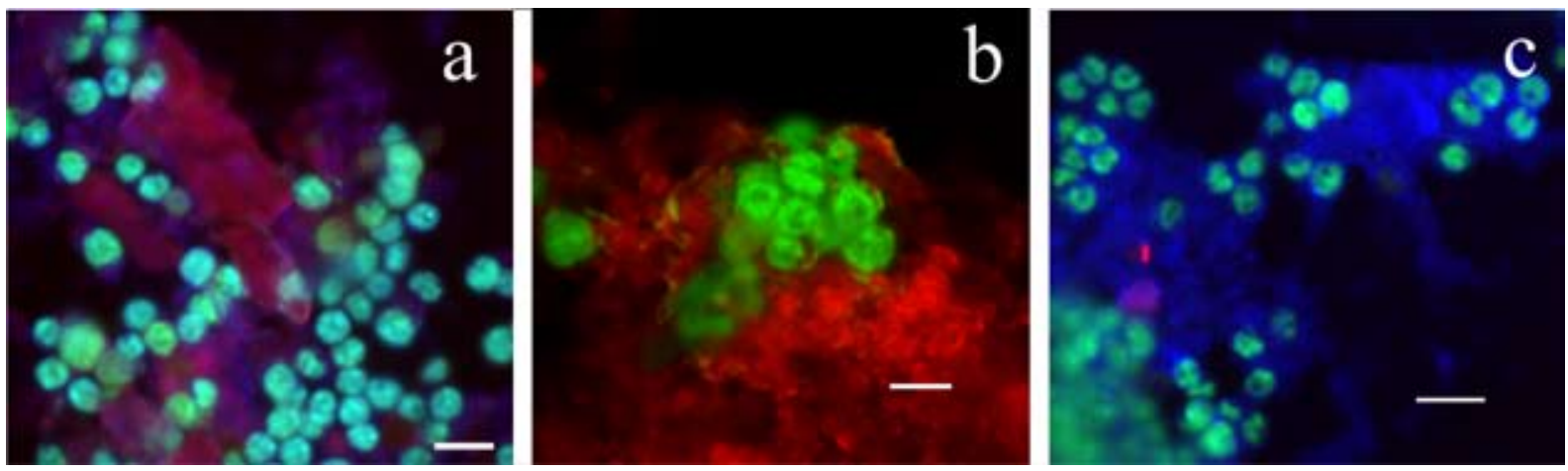

Fig. 4. Growth of coccal micro-algae on St Paul's artworks evidenced by epifluorescece microscopy: (c) aggregates grow inside calcite pore; (a) surrounded by thick polysaccharide matrix (blue); (b) surrounded by fiber calcite crystals. Red autofluorescence is of calcite. Scale bar $10 \mu \mathrm{m}$.

tolerance by regulating the loss and uptake of water (BILLI \& POTTS 2002).

Microscopic observation and enrichment culture usually allow only the recognition of Chroococcidiopsis morphotypes which are ubiquitous. However, community phylogenetic analysis has revealed considerable cyanobacterial diversity in the deserts of China (PoInting et al. 2007). Thus, the Chroococcidiopsis spp. identified in Maltese hypogea merit further study by community fingerprinting.

Chroococcal Asterocapsa cf. divina KoMÁReK
1993 and Gloeocapsa $\mathrm{cf}$. aeruginosa KüTZING 1843 (Fig 3) were successfully grown in culture from biofilms sampled from St Agatha's Catacombs and the Hal Saflieni hypogeum respectively. Gloeocapsa spp. (AsENCIO \& ABOAL 2000; ROLDAN \& HernándeZ-Mariné 2009), Chroococcidiopsis spp. (Asencio \& Aboal 2000) and Asterocapsa divina (ABOAL et al. 2003) were also observed to occur in different caves in Spain. Asterocapsa $\mathrm{sp}$. has also been reported from Leontari cave in Greece (LAMPRINOU et al. 2009). 

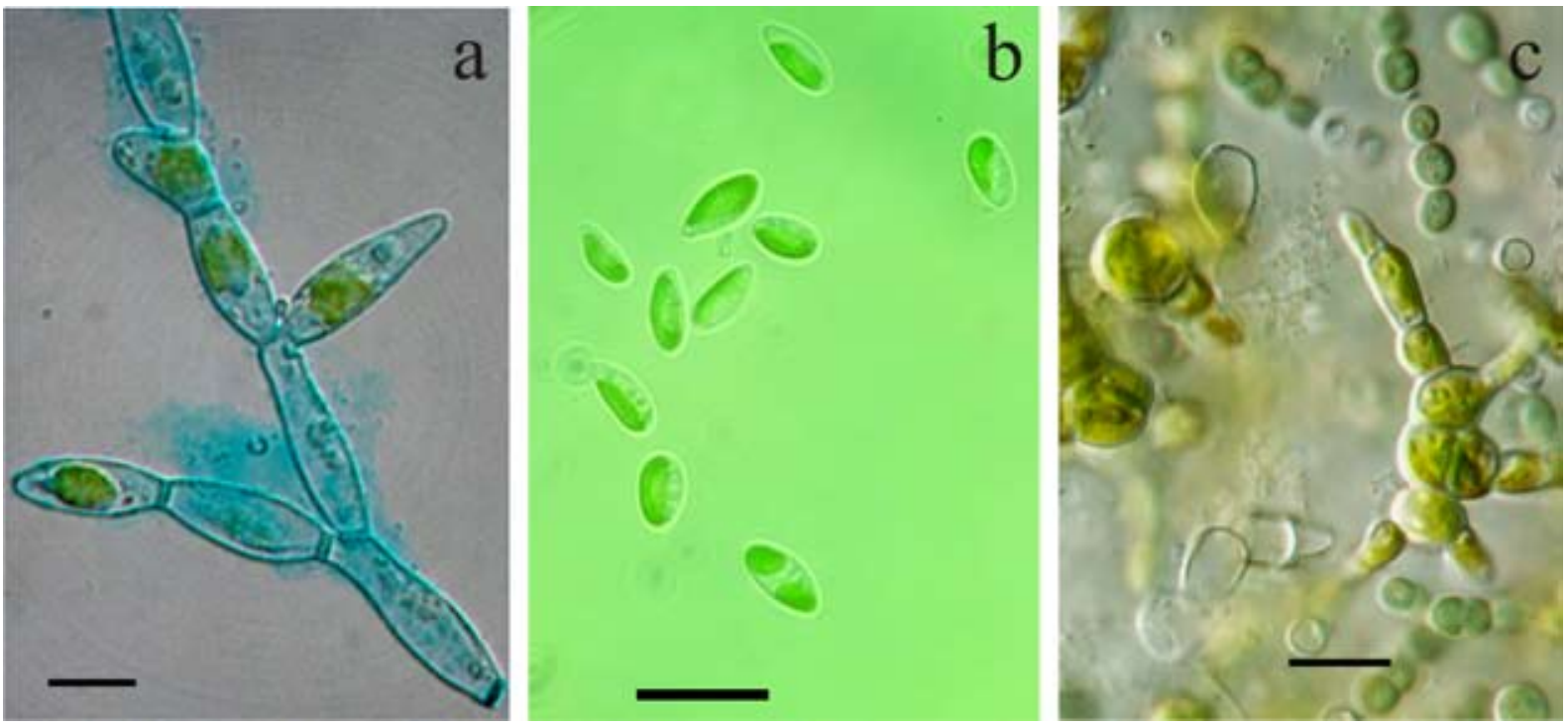

Fig. 5. Light micrographs of microalgae: (a) Trentepohlia morphotype; (b) Pseudoccoccomyxa sp.; (c) biofilm AD03 of Trentepohlia sp. and Pseudanabaena sp. growing in culture. Scale bar $10 \mu \mathrm{m}$.

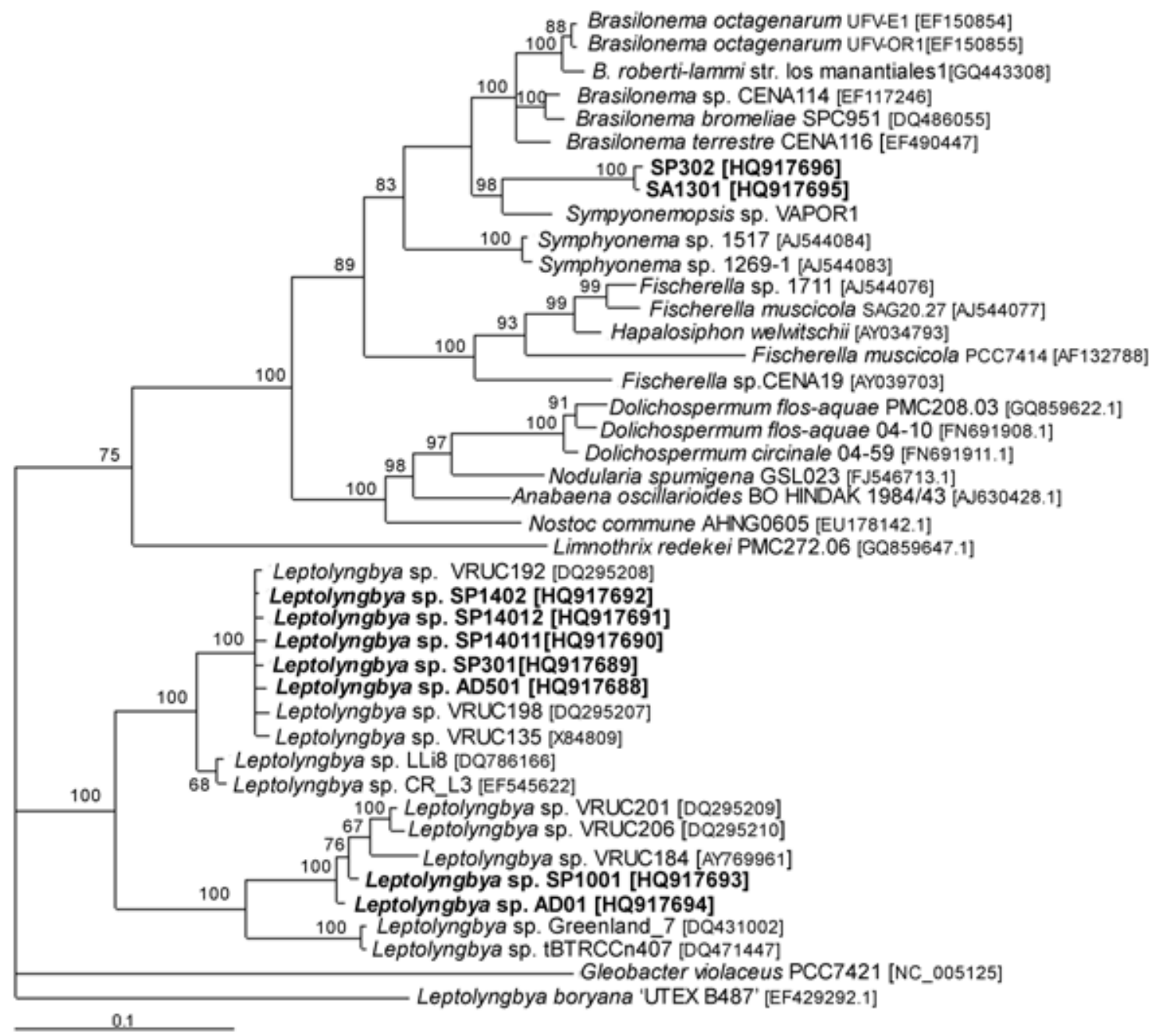

Fig. 6. Consensus tree from maximum parsimony and bayesian analysis showing the phylogenetic relationships between Oscillatorialean and Stigonematalean cyanobacterial strains isolated from Maltese hypogea and similar strains based on the 16S rRNA gene sequences. Gloeobacter violaceus PCC7421 was used as the outgroup. Strains isolated in this study are indicated in bold. Numbers near nodes indicate probability values obtained from Bayesian analysis. Scale represents number of substitutions per site. 


\section{Green algae}

Artworks of Maltese hypogea seem to support the growth of subaerial microalgae (Figs 4, 5) with relatively limited morphological types, which could be classified on the basis of morphology into two groups; the chlorococcalean Chlorella-like morphotype (Trebouxiophyceae, Chlorellales) and the filamentous Trentepohlia-like morphotype (Ulvophyceae, Trentepohliales) (Fig. 5a). These were generally observed growing in the biofilms in small populations as is a common occurrence with most subaerial algae (JoHN 1988). This fact, together with the small size of their cells, enabled accurate observation and examination only when grown in unialgal culture. However, even then, their proper classification was particularly problematic, due to the limited number of characters useful for a reliable morphological identification. Molecular methods were attempted, and while confirming the presence of those two taxa, the 18S rRNA data could not be resolved any further. Caution was exercised when comparing $18 \mathrm{~S}$ Trentepohlia and Chlorella sequences to those deposited in GenBank, since it has long been recognised that many of these organisms are misidentified and indeed belong to other taxa (Huss et al. 1999).

All the chlorococcalean algae observed had a thick, sometimes multilayered wall, whose surface appeared smooth or ribbed. Chlorococcalean algae of biofilm HYP 714 (Fig. 2a) had a parietal chloroplast with a pyrenoid and polysphosphate reserves. The number of autospores produced varied. Clonal cultures of these green algae are presently being studied further in terms of their ultrastructure, different stages in their life cycle, the presence of flagellated stages and molecular sequences based on a multi-gene approach.

Molecular data collected from microalgal groups in the last two decades has given rise to dramatic modifications at every level of classification, especially the genus level. In fact, several common genera of subaerial chlorophytes, such as Chlorella, have been shown to include species that in fact belong to different classes (Huss et al. 1999; Friedl \& O'Kelly 2002; Krienitz et al. 2003; Lewis \& McCourt 2004). In the case of terrestrial green algae, a great deal of genetic diversity is often hidden behind identical or very similar morphologies (LOPEZ-BAUTISTA et al. 2007).
Trentepohlia spp. (Figs 5 a, c) were responsible for biofilm formation on archaeological surfaces. Members of the genus Trentepohlia are very difficult to classify since some aspects of their biology and their life cycle have not been completely elucidated (RINDI \& GUIRY 2002). The morphology of the species is variable, and some are regarded as highly polymorphic organisms. Classification of species is based mainly on shape and size of vegetative cells, presence of setae, branching pattern, position and morphology of reproductive structures (PRINTZ 1939, 1964). However, some of these features are unstable and can vary in relation to ecological conditions. As has also been observed in another study (RINDI \& GuIRY 2002), Trentepohlia strains from Maltese hypogea exhibited slow growth in culture and they rarely produced structures, such as zoosporangia, that were useful for species-level determination (UYENCO 1965). Remarkably, an ecological study carried out in western Ireland, pointed out that species of Trentepohlia differed in their substratum preference (RINDI \& GUIRY 2002). All the Trentepohlia strains from Maltese hypogea were observed to grow preferentially on deteriorated, porous calcareous substrata.

One strain of Pseudococcomyxa cf. simplex (MaInX) FotT 1981 (Fig. 5b) (Trebouxiophyceae, Chlorellales) was grown in culture from AD13, a grey green biofilm growing on a limestone scroll adorning a Baldacchino tomb. Pseudococcomyxa spp. frequently occur in soils and other aeroterrestrial environments (ETTL \& GäRTNER 1995). Morphologically, this genus was distinguished from the similar genus Coccomyxa Schmidle by differences in mucilage production. The cultured Pseudococcomyxa cells had elongated, irregularly-shaped elliptical vegetative cells and produced a mucilaginous cap on the apical part of the cells. Neustupa and Nemjova (2008) found a significant correlation between the shape, ecology and morphology of six Pseudoccomyxa simplex strains, however the morphological differences are often minute. Recent molecular data indicate that, even though members of these two genera form a single trebouxiophycean clade, they are not differentiated into genera according to the traditional mucilage-production criterion (FRIEDL et al. 2007). The taxonomy of Coccomyxa-like green algae is thus still confusing (Kostikov et al. 2002) and the revision of this group will most certainly be based on molecular data (NeUstuPA \& 
Nemjova 2008).

The occurrence of diatoms in subaerophytic biofilms from Maltese hypogea was not frequent. However, in two cases, bright green biofilms on the archaeological surface at St Paul's Catacombs in very close proximity to light sources were caused by growth of diatoms. Biofilms SP04 and SP16 were complex phototrophic biofilms whose bright green colouration was due to the dense growth of pennate diatoms belonging to Diadesmis spp. KütZING 1844. The occurrence of Diadesmis spp. in subaerial biofilms is rare, but has also been previously reported from Roman catacombs (AlberTANo et al. 1995) and from cave environments (Roldan \& Hernandez-Marine 2009).

\section{Chemoorganotrophs}

Predominant bacterial strains obtained from qualitative cultural analysis were Gram-positive bacteria, mostly sporulating bacteria belonging to the genus Bacillus, (predominantly B. subtilis, $B$. aquimaris and $B$. cereus) and the filamentous actinobacteria Streptomyces spp., Micrococcus spp. CoHn 1872, Nocardia spp. and Isoptericola spp. Stackebrandt et al. 2004. Ribosomal Intergenic Spacer Analysis (RISA) showed different electrophoretic patterns in agreement with the morphological groups, thus confirming the bacterial diversity causing whitish/greyish alterations on the archaeological surface (ZAMMIT et al. 2008a; Zамmiт et al. 2009).

Fungi were rarely observed directly in the biofilm samples, but grew occasionally in culture. This is probably because ubiquitous spores of the genera Aspergillus Micheli 1729, Cladosporium LinK 1791, Penicillium FrIes 1832 and Mucor FresenIUS 1850 , are present in the biofilm and germinated in culture. Only in two cases were biofilms caused by the growth of fungi; SA24, a black alteration on a replica resin statue was due to the occurrence of Cladosporium sp. hyphae and spores (Zамmiт et al. 2009); and SP14, a reddish alteration on a deteriorated tomb ceiling was due to the growth of mycelia of Serpula lacrymans, (Schum. ex FR.) S.F. GraY spores of which probably seeped through the soil with infiltration water from the overlying gardens. Both taxa are well known to be associated with the biodeterioration of cultural heritage artifacts.

\section{Isolated cyanobacterial strains}

Strains of filamentous heterocytous (Stigonematalean) and non-heterocytous (Oscillatorialean) cyanobacteria isolated from subaerial biofilms were studied by microscopy and molecular techniques. Partial 16S rRNA gene sequences of the isolated cyanobacterial strains were used to construct the phylogenetic tree shown in Fig. 6.

The Stigonematalean strains (SP302 and SA1301 in Fig. 6) form part of a well supported main clade with other Stigonematalean and Nostocalean strains. Genetically and cytomorphologically they are similar to Brasilonema spp. and the latter were thus included in the phylogenetic analyses. It is interesting to note that the closest 16S rRNA sequence found in GenBank belongs to Symphyonemopsis sp. Vapor-1 isolated from the cave of El Vapor in Spain. Strains SP302 and SA1301 are described in more detail in ZАMMIT et al. 2010.

All the Leptolyngbya strains isolated in this study were phenotypically very simple. The filament diameter was approximately 1-4 $\mu \mathrm{m}$. The sheath was transparent and in some strains thick and mucilaginous. Necridic cells and false branching were observed in strains SP1001 and SP1402. The strains could be divided into two phenotypes on the basis of pigmentation, as shown by CLSM analysis; strains SP301, SP1401, SP1402 and AD501 were red, due to relatively high phycoerythrin content; strain SP1001 was green due to a relatively high phycocyanin content when compared to other strains. However, by using morphological criteria (KOMÁREK \& ANAGNOSTIDIS 2005) it was not possible to place these strains into one of the presently described species. The most similar descriptions to the strains isolated in this study are found in KOMÁREK \& ANAGNOSTIDIS (2005).; Leptolyngbya 'AlBerTano/KovaciK-red' 1997 for strains SP301, SP1401, SP1402 and AD501; and Leptolyngbya 'AlBERTANO/KovACIKgreen' 1992 for strain SP1001.

Leptolyngbya species normally possesses inflexible trichomes, nevertheless cell gliding of the trichomes was commonly observed for the strains isolated in this study. Moreover all the red Leptolyngbya strains isolated from the Maltese and Roman catacombs possess an 'orange spot' at the tip of the apical cell which resembles the eyespot (stigma) of carotenoid-rich lipid globules present 
in phototactic flagellated algae (AlberTANo et al. 2000). It has also been demonstrated that the red Leptolyngbya sp. strain VRUC 135, isolated from the Domus Aurea in Rome (also shown in the phylogenetic tree in Fig. 6) could turn towards a light source. The hypothesis is that Leptolyngbya strains possessing this 'orange spot' in the apical cell have ability to sense light is via a rhodopsinlike protein. In all the strains isolated in this study, the apical cell was rounded and in strains SP301, SP1401 and AD501 had a 'brownish-yellow cap'.

Ultrastructurally, their cytoplasm was characterised by the presence of carboxysomes, cyanophycin, lipid globules and interthylakoidal glycogengranules.Ultrastructural differencesincluded the structure and the thickness of the envelopes. However, sheath characteristics are often lost in culture, and thus this cannot be considered a reliable character. The thylakoid structure, which is not sensitive to varying environmental and culturing conditions, therefore provides a stable character that can be used to determine taxonomic relationships among thin-trichomed members of the Oscillatoriales. TEM sections showed that all the Oscillatorialean strains, isolated during this study had parietal thylakoids (Fig. 2 c, d).

Fig. 6 gives the topology and branch support observed in the consensus tree calculated from MB and MP analyses. Seven of the strains described as members of the genus Leptolyngbya are clustered into a highly supported clade. The six Leptolyngbya sp. strains isolated in this study form two clades with closely related Leptolyngbya sp. strains isolated from the catacombs in Rome. The top clade is the 'red clade' which contains strains high in PE; the second clade is the 'green clade' or strains with high PC content, as shown by CLSM analyses. A Leptolyngbya strain cloned directly from the biofilm AD01 also forms part of the green clade.

The green strains clustered into a group that was sister to a clade formed by two strains of Leptolyngbya, one benthic from Arctic hot springs; strain Greenland_7 (GenBank accession no. DQ431002, RoESELERS et al. 2007), the other a filamentous strain from thermal springs in Jordan named tBTRCCn407 (GenBank accession no. DQ471447, IONESCU et al. 2007). The red strains were sister to a clade formed by two strains of
Leptolyngbya sp. from a hot volcanic stream in Costa Rica; strain LLi 18 (GenBank accession no. DQ786166, FInSINGER \& Hess unpublished) and strain CR_L3 (GenBank accession no. EF545622, MorALES et al. unpublished). It would be interesting to investigate further these close relationships between Oscillatorialean strains from hypogean and geothermal habitats. Since these Oscillatorian cyanobacteria are still undersampled from a variety of habitats, this might have created an artefact in the analysis that would be corrected by including Oscillatorialean sequences from different environments.

In order to compare sequence similarity of the strains used in this study, a distance matrix was constructed (Table 2). Strains within the 'green' and 'red' Leptolyngbya clade were found have $16 \mathrm{~S}$ rRNA sequence similarity values above $95 \%$. The similarity for the green strains is higher than $98 \%$, for the red strains higher than $99 \%$. The sequence similarity between the red and the green strains was about $92 \%$. The high similarity between Leptolyngbya strains isolated from catacombs in Malta and Rome suggest that these might actually be morphologically variable ecophenes (phenotypic modifications produced within the same genotype due to environmental stimuli within the limits of the habitat under which the genotype is found in nature).

The cytomorphology and genetics of these hypogean strains are presently being studied further since their 16S rRNA clusters separately to the type species Leptolyngbya boryana, their ecology is different, and they possess specific characters which might be considered autapomorphic.

It can be concluded that the organisms forming biofilms in Maltese hypogea are similar morphologically to those colonising comparable habitats in the catacombs of Rome and those identified on lithic surfaces in various cave environments in Spain and Greece. Both cave and catacomb ecosystems can be classified as hypogean environments with rather stable conditions throughout the year, which seem to provide a refuge to these microorganisms. Specific hypogean environments may favour speciation, and various new cyanobacterial taxa have been described from this environment (LAMPRINOU et al. 2009). The isolated Oscillatorialean and Stigonematalean strains were also shown to be closely related to strains isolated from other catacomb and cave environments. 
The abundant EPS produced by the biofilm microorganisms as observed by microscopy of the investigated samples was crucial in their endurance on the archaeological surfaces by regulating the loss and uptake of water. The availability of liquid water as condensation droplets on the archaeological surface of these hypogean sites also played an important role in the activation of dormant or inactive cyanobacteria and microalgae (BoIson et al. 2004).

\section{Acknowledgements}

This research was endorsed by a Maltese government doctoral scholarship MGSS/2006/026, the Italian Ministry of Foreign Affairs Prot. No. 1540/09, the Czech Ministry of Education grant $06 / 1236 / 09$, the GAČR 206/08/0318, MSM 6007665801 and the EU SYNTHESYS grant GB-TAF-4608. The authors would like to show their appreciation to Jiří Košnar for his kind assistance in the phylogenetic analysis of data.

\section{References}

Aboal, M., Asencio, A. D. \& LóPez-Jiménez, E. (2003): Morphological, ultrastructural and ecological study of Asterocapsa divina Komárek (Chroococcaceae, Cyanobacteria) from a cave of Southeastern Spain. - Algological Studies 109: 57-65.

Allen, M. M. (1968) Simple conditions for growth of unicellular blue-green algae on plates. - Journal of Phycology 4: 1-3.

Asencio, A. D. \& Aboal, M. (2000): A contribution to knowledge of chasmoendolithic algae in cavelike environments. - Algological Studies 98: 133-151.

Albertano, P. \& Bellezza, S (2001): Cytochemistry of cyanobacterial exopolymers in biofilms from Roman hypogea. - Nova Hedwigia 123: 501518.

Albertano, P. \& KovaciK, L. (1994): Is the genus Leptolyngbya an homogeneous taxon? Algological Studies 75: 37-51.

Albertano, P. \& Urzì, C. (1999): Structural interactions among epilithic cyanobacteria and heterotrophic microorganisms in Roman hypogea. - Microbial Ecology 38: 244-252.

Albertano, P., Luongo, L. \& Grilli Caiola, M. (1989): Ultrastructural investigations on algae deteriorating Roman frescoes. - In: BAER, N., Sabbioni, C. \& Sors, A.I. (eds): Science, Technology and European Cultural Heritage. - pp. 501-504, Butterworth-Heinemann -
Oxford.

Albertano, P., KováčiK, L., Marvan, P. \& Grilli Caiola, M. (1995): A terrestrial epilithic diatom from Roman Catacombs. - In: MArino, D. \&. Montresor, M. (eds): Proceedings of the Thirteenth Inter. Diatom Symp. - pp. 11-21, Biopress Limited - Bristol.

Albertano, P., Barsanti, L., Passarelli, V. \& Gualtieri, P. (2000): A complex photoreceptive structure in the cyanobacterium Leptolyngbya sp. - Micron 31: 27-34.

Altschul, S.F., Gish, W., Miller, W., Myers, E.W. \& LipMAN D.J. (1990): Basic local alignment search tool. - Journal of Molecular Biology 215: 403-410.

Anagnostidis, K. \& KomÁreK, J. (1985a): Modern approach to the classification system of Cyanophytes 1 - Introduction. - Algological Studies 38-39: 291-302.

Anagnostidis, K. \& KomÁrek, J. (1985b): Modern approach to the classification system of Cyanophytes 3 - Oscillatoriales. - Algological Studies 50-53: 327-472.

Berard, A., Dorigo, U., Humbert, J.F. \& MartinLAURENT, F. (2005): Microalgae community structure analysis based on $18 \mathrm{~S}$ rDNA amplification from DNA extracted directly from soil as a potential soil bioindicator. - Agronomie 25: $1-7$.

Billi, D. \& PotTs, M. (2002): Mini-review Life and death of dried prokaryotes. - Research in Microbiology 153: 7-12.

Bischoff, H.W. \& Bold, H.C. (1963): Phycological Studies IV. Some algae from Enchanted Rock and related algal species. - University of Texas Publications 6318: 1-95.

Boison, G., Mergel, A., Jolkver, H. \& Bothe, H. (2004): Bacterial Life and Dinitrogen Fixation at a Gypsum Rock. - Applied and Environmental Microbiology 70: 7070-7077.

Boyer, S.L., Flechtner, V.R. \& Johansen, J.R. (2001): Is the 16S-23S rRNA Internal Transcribed Spacer region a good tool for use in molecular systematics and population genetics? A case study in cyanobacteria. - Molecular Biology and Evolution 18: 1057-69.

Bruno, L., Billi, D. \& Albertano, P. (2006): Genetic Characterization of Epilithic Cyanobacteria and Their Associated Bacteria. - Geomicrobiology Journal, 23:293-299.

Bruno, L., Billi, D., Bellezza S. \& Albertano, P. (2009): Cytomorphological and Genetic Characterization of Troglobitic Leptolyngbya Strains Isolated from Roman Hypogea. Applied and Environmental Microbiology 75: 608-617.

Diez, B., Pedros-Alio, C., Marsh, T.L. \& Massana, R. (2001): Application of Denaturing Gradient Gel 
Electrophoresis (DGGE) To Study the Diversity of Marine Picoeukaryotic Assemblages and Comparison of DGGE with Other Molecular Techniques. - Environmental Microbiology 67: 2942-2951.

Dodds, W.K., Gudder, D.A. \& Mollenhauer, D. (1995): The ecology of Nostoc. - Journal of Phycology 31: 2-18.

EtrL, H. (1978) Xantophyceae 1. Teil. - In: EтtL, H., Gerloff, J. \& Heynig, H. (eds): Süßwasserflora von Mitteleuropa, Vol. 3. - 530 pp., Gustav Fischer Verlag, Jena.

EtTL, H. (1983): Chlorophyta I (Phytomonadina). - In: Ettl, H., Gerloff, J., Heynig, H. \& Mollenhauer, D. (eds): Süßwasserflora von Mitteleuropa, Vol. 9. - 807 pp., Gustav Fischer Verlag, Jena.

EtTL, H. \& Gärtner, G. (1988): Chlorophyta II (Tetrasporales, Chlorococcales, Gloeodendrales). - In: EtTl, H., Gerloff, J. \& Heynig, H. (eds): Süßwasserflora von Mitteleuropa, Vol. 10. - 436 pp., Gustav Fischer Verlag, Jena.

Ettl, H. \& Gartner, G. (1995): Syllabus der Boden-, Luft- und Flechtenalgen. - 721 pp., G. Fischer Verl., Stuttgart.

Evans, R.D. \& Johansen, J.R. (1999): Microbiotic crusts and ecosystem processes. - Critical Reviews in Plant Sciences 18:183-225.

Friedl, T. \& O'Kelly, C.J. (2002): Phylogenetic relationship of green algae assigned to the genus Planophila (Chlorophyta): evidence from $18 \mathrm{~S}$ rDNA sequence data and ultrastructure. European Journal of Phycology 37: 373-84.

Friedl, T., Kostikov, I., Müller, J., Beck, A., Zufall-Roth, E. \& HoffmanN , L. (2007): An investigation of Pseudococcomyxa (Chlorophyta, Trebouxiophyceae): morphology, rDNA sequencing and AFLP fingerprinting to define species. - Proc. Abstr. Int. Conf. Taxonomy and Biology of Green Algae V., Smolenice.

Garcia-Pichel, F., Nübel U. \& Muyzer, G. (1998): The phylogeny of unicellular, extremely halotolerant cyanobacteria. - Archives of Microbiology 169: 469-482.

Geitler, L. (1932): Cyanophyceae. - In: Rabenhorst's Kryptogamenflora 14/2. - 1196 pp., Akad. Verlagsges, Leipzig.

Gugger, M.F. \& Hoffmann, L. (2004) Polyphyly of true branching cyanobacteria (Stigonematales). - International Journal of Systematic and Evolutionary Microbiology 54: 349-357.

HALl, T.A. (1999): BioEdit: a user-friendly biological sequence alignment editor and analysis program for Windows 95/98/NT. - Nucleic Acids Symposium Series 41: 95-98.
Hasegawa, M., Kishino, H., \& Yano, T. (1985): Dating of the human-ape splitting by a molecular clock of mitochondrial DNA. - Journal of Molecular Evolution 22:160-174.

Helm, R.F., Huang, Z., Edwards, D., Leeson, H., Peery, W. \& Potts, M. (2000): Structural Characterization of the Released Polysaccharide of Desiccation-Tolerant Nostoc commune DRH-1. - Journal of Bacteriology 182: 974982.

Hernández-Mariné, M., Asencio-Martínez, A., Canals, A., Ariño, X., Aboal, M. \& Hoffmann, L. (1999): Discovery of populations of the lime incrusting genus Loriella (Stigonematales) in Spanish caves. - Algological Studies 94: 121138.

Huss, V.A.R., Frank, C., Hartmann, E.C., Hirmer, M., Kloboucek, A., Seidel, B.M., Wenzeler, P. \& KessLer, E. (1999): Biochemical taxonomy and molecular phylogeny of the genus Chlorella sensu lato (Chlorophyta). - Journal of Phycology 35: 587-598.

Ionescu, D., Oren, A., Hindiyeh, Y. \& Malkawi, H.I. (2007): The thermophilic cyanobacteria of the Zerka Ma'in thermal springs in Jordan. - In: Seckbach, J. (ed.): Algae and cyanobacteria in extreme environments. - pp. 413-424, Springer, Dordrecht, The Netherlands.

JoHN, D.M. (1988): Algal growths on buildings: a general review and methods of treatment. Biodeterioration Abstracts 2, 81-102.

John, D.M., Whitton, B.A. \& Brook, A.J. (2002): The Freshwater Algal Flora of the British Isles. 702 pp., Cambridge University Press, UK.

KING, A.D., Hocking A.D. \& PITT, J.I. (1979): Dichloran-rose bengal medium for enumeration and isolation of molds from foods. - Applied and Evnironmental Microbiology 37: 959-964.

KomáreK, J. (2002): Problems in cyanobacterial taxonomy; implication for most common toxin producing species. - In: Melchiorre, S., Viaggiu, E. \& BRuno, M. (eds): Rapporti Istituto Superiore di Sanitá. - pp. 6-43, Roma.

KomÁreK, J. (2003): Planktic oscillatorialean cyanoprokaryotes (short review according to combined phenotype and molecular aspects). Hydrobiologia 502: 367-382.

KomÁReK J. (2007): Phenotype diversity of the cyanobacterial genus Leptolyngbya in the maritime Antarctic. - Polish polar Research 28: 211-231.

KomÁReK, J. \& FotT, B. (1983): Chlorococcales. - In: Huber-Pestalozzi, G. (ed.): Das Phytoplankton des Süßwassers, Vol. 7. - 1043 pp., Schweizerbart, Stuttgart.

KomáreK, J. \& Anagnostidis, K. (1998): Cyanoprokaryota 1 (Chroococcales). - In: ETTL H., Gärtner, G. \& Heynig, H. \& Mollenhauer 
D. (eds): Süßwasserflora von Mitteleuropa, 19/1.- 548 pp., Gustav Fischer, Jena.

KomÁreK, J. \& Anagnostidis, K. (2005): Cyanoprokaryota2(Oscillatoriales).-In:BüDEL, B., Krienitz, L., Gärtner, G. \& Schagerl, M. (eds): Süßwasserflora von Mitteleuropa, 19/2.759 pp., Elsevier/ Spektrum, Heidelberg.

Kostikov, I., Darienko, T., Lukešová, A. \& Hoffmann, L. (2002): Revision of the classification system of Radiococcaceae Fott ex Komárek (except the subfamily Dictyochlorelloideae) (Chlorophyta). - Algological Studies 104: 23-58.

Krammer, K. \& Lange-Bertalot, H. (1986) Bacillariophyceae 1. Teil. - In: Ettr, H., GerL off, J., Heynig, H. \& Mollenhauer, D. (eds): Süßwasserflora von Mitteleuropa, 2/1. - 875 pp., Gustav Fischer Verlag, Jena.

Krammer, K. \& LANGe-Bertalot, H. (1988): Bacillariophyceae 2. Teil. - In: EtTL, H., Gerloff, J., Heynig, H. \& Mollenhauer, D. (eds): Süßwasserflora von Mitteleuropa, 2/2. 596 pp., Gustav Fischer Verlag, Jena.

Krammer, K. \& Lange-Bertalot, H. (1991a): Bacillariophyceae 3. Teil. - In: EtTL, H., Gerloff, J., Heynig, H. \& Mollenhauer, D. (eds): Süßwasserflora von Mitteleuropa, 2/3. 576 pp., Gustav Fischer Verlag, Stuttgart.

Krammer, K. \& Lange-Bertalot, H. (1991b): Bacillariophyceae 4. Teil.-In: EtTL, H., GÄRTNER G., Gerloff, J., Heynig, H. \& Mollenhauer, D. (eds): Süßwasserflora von Mitteleuropa, 2/4. 436 pp., Gustav Fischer Verlag, Stuttgart.

Krienitz, L., Hegewald, E., Hepperle, D. \& Wolf, A. (2003): The systematics of coccoid green algae: 18S rRNA gene sequence data versus morphology. - Biologia 58: 437-446.

Lamprinou, V. Pantazidou, A., Papadogiannaki G., RadeA, C. \& Economou-Amill, A. (2009) Cyanobacteria and associated invertebrates in Leontari Cave, Attica (Greece). - Fottea 9: 155-164.

Lerch, K \& Ettlinger, L. (1972): Purification and characterization of a tyrosinase from Streptomyces glaucescens. - European Journal of Biochemistry 31: 427-437.

Lewis, L.A. \& McCourt, R.M. (2004): Green algae and the origin of land plants. - American Journal of Botany 91: 1535-1556.

Lopez-Bautista, J., Rindi, F. \& Casamatta, D. (2007): The systematics of subaerial algae. - In:. SECKBACH J. (ed.): Algae and Cyanobacteria in Extreme Environments. - pp. 599-617, Springer, The Netherlands.

Meeks, J.C., Elhai, J., Thiel, T., Potts, M., Larimer, F., Lamerdin, J., Predki, P. \& Atlas, R. (2001): An overview of the genome of Nostoc punctiforme, a multicellular, symbiotic cyanobacterium. Photosynthesis Research 70: 85-106.
Migula, W. (1907): Algen. - In: Kryptogamen-Flora von Deutschland, Deutsch-Österreich und der Schweiz 2, Teil 1, Zezschwitz Verlag, Gera.

Neustupa, J. \& NemjovÁ, K. (2008): Quantitative assessment of morphological variation of six Pseudococcomyxa strains by geometric morphometric descriptors. - Fottea 8: 111-116.

PAerL, H.W. (1992): Epi- and endobiotic interactions of cyanobacteria. In: ReISSER, W. (ed) Algae and Symbioses: Plants, Animals, Fungi, Viruses, Interactions Explored. - pp. 537-565, Biopress, Bristol.

Pointing, S.B., Warren-Rhodes, K.A., Lacap, D.C., Rhodes, K.L. \& McKay, C.P. (2007): Hypolithic community shifts occur as a result of liquid water availability along environmental gradients in China's hot and cold hyperarid deserts. Environmental Microbiology 9: 414-424.

Prescott, G.W., Croasdale, H.T. \& Vinyard, W.C. (1972): A synopsis of North American desmids. Part 1, Mesotaeniaceae: Saccodermae. In: Rogerson, C.T. (ed.): North American Flora, II/6. - 84 pp., The New York Botanical Garden.

PrINTZ, H. (1939): Vorarbeiten zu einer Monographie der Trentepohliaceen. - Nytt. Mag. Naturvbidensk. 80: $137-210$.

Printz, H. (1964): Die Chaetophoralen der Binnengewässer. - Hydrobiologia 24: 1-376.

Reynolds, C.S. (1963): The use of lead citrate at high $\mathrm{pH}$ as an electron-opaque stain in electron microscopy. - Journal of Cellular Biology 17: 208-212

Rindi, F., Sherwood, A.R. \& Guiry, M.D (2002): Diversity, Life History and ecology of Trentepohlia and Printzina (Trentepohliales, Chlorophyta) in urban habitats in western Ireland. - Journal of Phycology 38: 39- 54.

Rindi, F., Sherwood, A.R. \& Guiry, M.D. (2005): Taxonomy and distribution of Trentepohlia and Printzina (Trentepohliales, Chlorophyta) in the Hawaiian Islands. - Phycologia 44: 270- 284.

Rodríguez, F., Oliver, J.L., Marín, A., Medina, J.R. (1990): The general stochastic model of nucleotide substitution.- Journal of Theoretical Biology 142: 485-501.

Roeselers, G., Norris, T.B., Castenholz, R.W., RysgaArd, S., Glud, R.N., Kuhl, M. \& Muyzer, G. (2007): Diversity of phototrophic bacteria in microbial mats from Arctic hot springs (Greenland). - Environmental Microbiology 9:26-38.

Roland, J.C., Lembi, C.A. \& Morre, D.G. (1972): Phosphotungstic acid chromic as a selective electron dense stain for plasma membrane of plant cells. - Stain Technology 45: 195-200.

Roldan, M. \& Hernandez-Marine, M. (2009): Exploring the secrets of the three-dimensional 
architecture of phototrophic biofilms in caves. International Journal of Speleology 38: 41-53.

Ronquist, F. \& Huelsenbeck J.P. (2003) MrBayes 3: Bayesian phylogenetic inference under mixed models. - Bioinformatics 19: 1572-1574.

SaArela, M., Alakomi, H.M., Suihko, M.L., Maunuksela, L., RaAska, L. \& MattilaSANDHOLM T. (2004): Heterotrophic microorganisms in air and biofilm samples from Roman catacombs, with special emphasis on actinobacteria and fungi. - International Biodeterioration and Biodegradation 54: 27 37.

Stomp, M., Huisman, J., de Jongh, F., Veraart, A.J., Gerla, D. \& Rijkeboer, M. (2004): Adaptive divergence in pigment composition promotes phytoplankton biodiversity. - Nature 432: 104 107.

Swofford, D.L. (2002): PAUP*. Phylogenetic Analysis Using Parsimony (*and other methods). Version 4. Sinauer Associates, Sunderland, Massachusetts.

Taton, A., Grubisic, S. \& Wilmotte A. (2002): Cyanobacterial diversity in Antarctic microbial mats.- In: Solmeim, B. (ed), Cyanobacteria and Nitrogen Fixation in Extreme Environments. - p. 22, Eur. Sci. Found. CYANOFIX, Longyearbyen.

THIÉRY J.P.(1967):Mise enévidence des polysaccharides sur coupes fines en microscopie électronique. Journal of Microscopy 6: 987-1018.

Urzi, C., \& De Leo, F. (2001): Sampling with adhesive tape strips: an easy and rapid method to monitor microbial colonization on monument surfaces. Journal of Microbiological Methods 44: 1-11.

Uyenco, F.R. (1965): Studies on some lichenized Trentepohlia associated in lichen thalli with Coenogonium. - Trans. Am. Microsc. Soc. 84:1-14.

Watanabe, M.M. (1999): Network approach to make biodiversity information accesible worldwide. In: Species 2000, Abstracts of the International Workshop for Studies on Biodiversity. - p. 13, Tsukuba.

Wehr, J.D. \& SheAth, R.G. (eds) (2003): Freshwater Algae of North America: Classification and Ecology. - 918 pp., Academic Press, New York.

Wilmotte, A. \& Golubić, S. (1991): Morphological and genetic criteria in the taxonomy of Cyanophyta/ Cyanobacteria. - Algological Studies 64: 1-24.

Zammit, G., De Leo, F., Albertano, P. \& Urzì, C. (2008a): A preliminary comparative study of microbial communities colonizing ochredecorated chambers at the Hal Saflieni Hypogeum at Paola, Malta. - In: LukAszewicz, J.W. \& Niemcewicz P. (eds): Prodeedings of the 11th International Congress on Stone
Deterioration. - pp. 555-562, Nicolaus Copernicus University Press, Torun, Poland.

Zammit, G., Psaila, R. \& Albertano, P. (2008b): An investigation into biodeterioration caused by microbial communities colonising artworks in Maltese Palaeo-Christian Catacombs. - In: Notea A. \& Shoef Y. (eds): Art 2008 Conference Proceedings, -9 th International Conference on Non-destructive testing, microanalysis and preservation in the conservation of cultural and environmental heritage. - pp. 1-10, ISAS International Seminars Ltd., Jerusalem, Israel.

Zammit, G., De Leo, F., Urzì, C., \&Albertano, P.(2009): A non-invasive approach to the polyphasic study of biodeteriogenic biofilms at St Agatha Crypt and Catacombs at Rabat, Malta. - In: Meli, G. (ed.): Science and Cultural Heritage in the Mediterranean Area- Prodeedings of the third International Conference on Materials and the Signs of History. - pp. 323-327, Department of Environmental and Cultural Heritage, Palermo, Italy.

Zammit, G., Kaštovský, J. \& Albertano, P. (2010): A first cytomorphological and molecular characterisation of a new Stigonematalean cyanobacterial morphotype isolated from Maltese catacombs. - Algological Studies 135:1-14.

(C) Czech Phycological Society (2011)

Recieved Sept 2010

Accepted Dec 2010 
Table 1. Predominant taxa observed in biofilms from St. Agatha's (SA), St. Paul's (SP), Abbatija tad-Dejr (AD), Hal-Saflieni (HYP); (F) filamentous, (C) coccal, (Pr) prokaryotic, (E) eukaryotic, (P) photosynthetic, (H) heterotrophic, (WP) wall painting, (R) rock.

\begin{tabular}{|c|c|c|c|c|}
\hline Site & Name & Morphology & Substrate & Nutrition \\
\hline \multirow[t]{17}{*}{ SA } & Leptolyngbya spp. & $\mathrm{F}, \operatorname{Pr}$ & WP, R & $\mathrm{P}$ \\
\hline & Fischerella sp. & F, Pr & WP, R & $\mathrm{P}$ \\
\hline & Streptomyces spp. & $\mathrm{F}, \operatorname{Pr}$ & WP, R & $\mathrm{H}$ \\
\hline & Nocardia spp. & F, Pr & WP, R & $\mathrm{H}$ \\
\hline & Isoptericola spp. & $\mathrm{F}, \operatorname{Pr}$ & WP, R & $\mathrm{H}$ \\
\hline & Bacillus spp. & Rods, $\operatorname{Pr}$ & WP, R & $\mathrm{H}$ \\
\hline & Chroococcidiopsis spp. & $\mathrm{C}, \operatorname{Pr}$ & WP, R & $\mathrm{P}$ \\
\hline & Nostoc spp. & $\mathrm{F}, \operatorname{Pr}$ & WP, R & $P$ \\
\hline & Moss protonemata & $\mathrm{F}, \mathrm{E}$ & WP, R & $\mathrm{P}$ \\
\hline & Asterocapsa spp. & $\mathrm{C}, \operatorname{Pr}$ & WP, R & $\mathrm{P}$ \\
\hline & Cladosporium spp. & spores & WP, R & $\mathrm{H}$ \\
\hline & Aspergillus spp. & spores & WP, R & $\mathrm{H}$ \\
\hline & Fusarium spp. & spores & WP, R & $\mathrm{H}$ \\
\hline & Penicillium spp. & spores & WP, R & $\mathrm{H}$ \\
\hline & Pseudopleurococcus sp. & $\mathrm{F}, \mathrm{E}$ & WP, R & $\mathrm{P}$ \\
\hline & Trentepohlia sp. & $\mathrm{F}, \mathrm{E}$ & WP, R & $\mathrm{P}$ \\
\hline & Chlorella spp. & $\mathrm{C}, \mathrm{E}$ & WP, R & $\mathrm{P}$ \\
\hline \multirow[t]{9}{*}{ SP } & Serpula lacrymans & $\mathrm{F}, \mathrm{E}$ & $\mathrm{R}$ & $\mathrm{H}$ \\
\hline & Chlorella spp. & $\mathrm{C}, \mathrm{E}$ & WP, R & $\mathrm{P}$ \\
\hline & Trentepohlia sp. & $\mathrm{F}, \mathrm{E}$ & WP, R & $\mathrm{P}$ \\
\hline & Leptolyngbya spp. & F, Pr & WP, R & $\mathrm{P}$ \\
\hline & Fischerella sp. & $\mathrm{F}, \operatorname{Pr}$ & WP, R & $\mathrm{P}$ \\
\hline & Diadesmis spp. & $\mathrm{C}, \mathrm{E}$ & WP, R & $\mathrm{P}$ \\
\hline & Chroococcidiopsis spp. & $\mathrm{C}, \mathrm{Pr}$ & WP, R & $P$ \\
\hline & Actinobacteria & F, Pr & WP, R & $\mathrm{P}$ \\
\hline & Fungi & spores & WP, R & $\mathrm{H}$ \\
\hline \multirow[t]{9}{*}{$\mathrm{AD}$} & Leptolyngbya spp. & $\mathrm{F}, \operatorname{Pr}$ & WP, R & $\mathrm{P}$ \\
\hline & Trentepohlia sp. & $\mathrm{F}, \mathrm{E}$ & WP, R & $\mathrm{P}$ \\
\hline & Pseudanabaena sp. & F, Pr & WP, R & $\mathrm{P}$ \\
\hline & Nostoc spp. & F, Pr & WP, R & $\mathrm{P}$ \\
\hline & Chlorella spp. & $\mathrm{C}, \mathrm{E}$ & WP, R & $\mathrm{P}$ \\
\hline & Pseudococcomyxa simplex & $\mathrm{C}, \mathrm{E}$ & $\mathrm{R}$ & $\mathrm{P}$ \\
\hline & Moss protonema & $\mathrm{C}, \mathrm{E}$ & WP, R & $\mathrm{P}$ \\
\hline & Actinobacteria & $\mathrm{F}, \operatorname{Pr}$ & WP, R & $\mathrm{P}$ \\
\hline & Fungi & spores & WP, R & $\mathrm{H}$ \\
\hline \multirow[t]{8}{*}{ HYP } & Leptolyngbya spp. & F, Pr & WP, R & $\mathrm{P}$ \\
\hline & Chlorella spp. & $\mathrm{C}, \mathrm{E}$ & WP, R & $\mathrm{P}$ \\
\hline & Gleocapsa spp. & $\mathrm{C}, \operatorname{Pr}$ & WP, R & $\mathrm{P}$ \\
\hline & Bacillus spp. & Rods, Pr & WP, R & $\mathrm{H}$ \\
\hline & Streptomyces spp. & F, Pr & WP, R & $\mathrm{H}$ \\
\hline & Micrococcus spp. & $\mathrm{C}, \mathrm{Pr}$ & WP, R & $\mathrm{H}$ \\
\hline & Aspergillus spp. & spores & WP, R & $\mathrm{H}$ \\
\hline & Actinobacteria & $\mathrm{F}, \operatorname{Pr}$ & WP, R & $\mathrm{P}$ \\
\hline
\end{tabular}




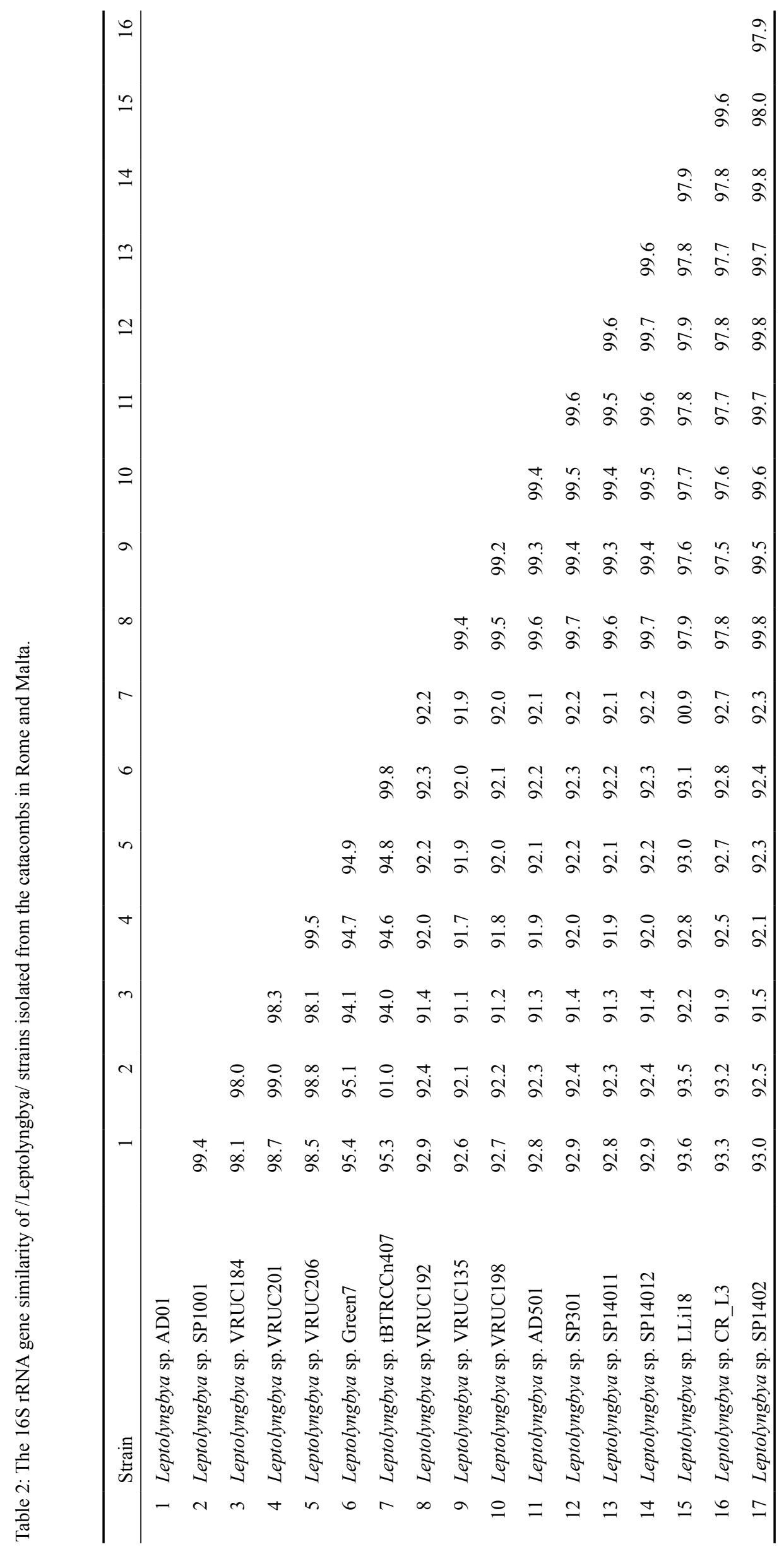

